\title{
부산정관에너지 전력케이블 화재사례 분석 Analysis of the Power Cable Fire Case in Busan-JungKwan Energy
}

\author{
지홍근* · 조영진** \\ Ji, Hongkeun*, and Cho, Youngjin**
}

\begin{abstract}
In this paper, the fire cause of blackout occurred in the Busan-JungKwan Energy as a Community Energy System (CES) was analyzed. Through analysis of the data such as burn patterns at the site, melted shape of cable head by the fire, overcurrent relay (OCR) of the control system, and event log, it was confirmed that first ground fault occurred at the termination connection of secondary cable of transformer. It was concluded because the void space of insulation and electrical melting trace conductor were investigated in the cable stress cone by detailed investigation and X-ray inspection for cable termination. In addition, as the damage by the tool on the vertical direction to the conductor was identified, it was presumed that the accident occurred by deterioration progress of insulation which was accelerated than that of the other parts.
\end{abstract}

Key words : Power Cable Fire, Fire Investigation, Electrical Fire, CES (Community Energy System), Cable Head

\section{요 지}

본 논문에서는 구역전기사업자인 부산정관에너지에서 화재가 발생하여 도시에 블랙아웃이 발생한 사례의 화재원인을 분석하였 다. 현장의 연소 형상, 케이블 종단접속부의 소훼 형상, 사고 발생 시 제어시스템의 과전류계전기 데이터, 이벤트 로그 데이터 등의 분석을 통해 변압기 2차측의 케이블 종단접속 부분 중, $\mathrm{B}$ 상에서 최초 지락 고장이 발생하였음을 확인하였다. 케이블 종단접속 부분의 X-ray 검사 및 분해 검사를 통해 B-1 케이블의 스트레스 콘 내부에서 절연체의 천공 흔적 및 도체의 전기적 용융흔적을 확인함으로써, B-1 케이블 내부에서 최초 지락 고장이 발생한 것으로 한정할 수 있었다. 또한, 케이블 절연체의 천공된 부위에서 도체에 수직방향으로 공구에 의해 손상된 흔적이 식별되는 상태로써, 케이블 접속 과정에서 절연체가 손상되어 다른 부위보다 빠르게 열화가 진행되면서 사고가 발생하였을 것으로 추정하였다.

핵심용어 : 전력케이블화재, 화재조사, 전기화재, 구역전기사업, 케이블 종단접속부

\section{1. 서 론}

산업의 고도화 및 정보화로 국민들의 생활 수준이 항상됨 에 따라 전기에너지의 수요는 지속적으로 증가하고 있다. 2013년 기준으로 국내 총발전량은 537,169 GWh에서, 2018 년에는 593,407 GWh로 5년 동안 약 $6.6 \%$ 가 증가하였으며, 발전량이 증가함에 따라 발전소, 변전소 및 송전탑 등의 수요도 커지고 있으나, 환경오염으로 인한 반대여론으로
인해 발전소 및 송전설비의 건립이 쉽지 않은 상황이다 (KEPCO, 2019). 이러한 여건의 대안으로 에너지 절약정책 과 증가하는 전력수요에 대응하기 위해 수요지 중심의 분산 형 전원확대정책으로 구역전기사업을 추진하였다 $(\mathrm{Kim}$, 2019). 구역전기사업은 대규모 아파트 단지, 호텔, 병원 및 산업 단지 등 다량의 전력수요가 발생하는 지역 근처에 열병합발전소를 설립하여 전기와 난방열을 생산하고 사용 자에게 직접 공급함으로써 전력계통의 안정성을 제고할 
것으로 기대받았다. 하지만, 에너지생산원가의 상승에 비해 전기 및 열에너지 요금이 충족되지 못함에 따라 구역전기사 업자들의 경영난이 심화되었으며, 구역전기사업소에서 사 고가 발생할 경우, 구역 전체에 대규모 정전 사태가 발생하여 크나큰 사회 혼란을 야기할 수 있는 단점이 있다(Choi, 2012).

본 논문에서는 2017년 부산 정관신도시 택지지구 내 아파 트 및 공공·상업시설에 전기를 공급하는 구역전기사업자 가 운용하는 발전소의 전력케이블에서 화재가 발생하여, 아파트 22,800여 가구와 공공 및 상업시설 등 신도시 전체가 9시간 동안 블랙아웃(대규모 정전사고)이 발생한 화재사고 의 원인조사 내용에 대해 기술하였다.

\section{2. 이 론}

\section{1 전력용 케이블 종류 및 구조}

우리나라에서 사용하는 전력용 케이블은 분야별로 초고 압 케이블, 가공선, 중 - 저압 케이블 및 산업용 특수 케이블 등으로 나누어진다. 초고압 케이블은 최근 전력수요의 증가 에 따른 송전 용량의 대용량화, 유지보수의 편리성과 전력공 급의 신뢰성, 안전성의 요구로 인하여 지중화되고 있다(Bae, 2015; Park and Lee, 2015). 가공선으로는 강심 알루미늄 연선(Aluminium-conductor Steel-reinforced Cable)과 이에 비해 많은 전력공급이 필요한 경우에 사용되는 증용량 케이블 (High Capacity Conductor) 및 통신기능을 포함한 광복합 가공지선(Optical Ground Wire) 등이 사용된다. $22.9 \mathrm{kV}$ 용으 로는 일반적으로 $\mathrm{CN} / \mathrm{CV}, \mathrm{CN} / \mathrm{CV}-\mathrm{W}, \mathrm{FR} \mathrm{CN} / \mathrm{CO}-\mathrm{W}$, TR $\mathrm{CN} / \mathrm{CE}-\mathrm{W}, \mathrm{OC}-\mathrm{W}, \mathrm{ABC}-\mathrm{W}$ 등이 사용되며, 사용전압 $6.6 \mathrm{kV}$ 이하로는 $\mathrm{CV}$ 등이 주로 사용된다.

일반적인 $22.9 \mathrm{kV}$ 전력케이블은 도체(Conductor), 도체차 폐층(Conductor Screen: 내부 반도전층), 절연체(Insulator), 절연차폐층(Insulation Screen: 외부 반도전층), 중성선 (Neutral Wire) 및 외피(Sheath)로 구성되며, 이 중 반도전층 은 내부에 걸리는 전계 및 방사 전기장를 균일하게 하고, 공기층 발생을 방지하여 케이블의 절연을 유지시킨다. 사고 가 발생한 정관에너지 변압기에 연결된 케이블은 FR-CV로 서 내부 구조는 아래 Fig. 1과 같다(LS Cable \& System Ltd.; Taihan Electric Wire Co. Ltd.).

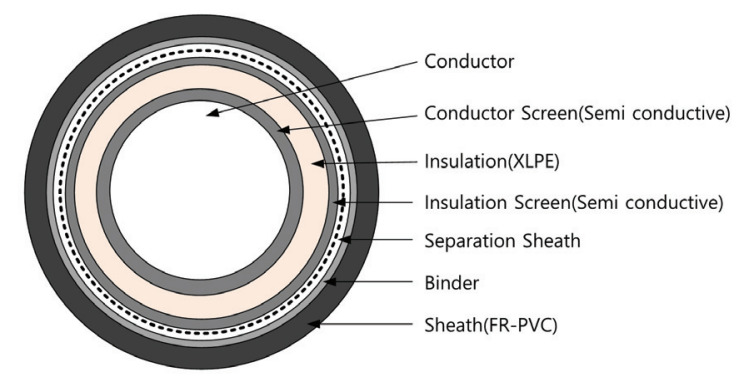

Fig. 1. Cable Structure (FR-CV)

\section{2 케이블 종단접속부}

고압 및 특고압 케이블 접속에 있어 케이블 차폐층 종단부 가 케이블의 절연 효과를 해칠 우려가 있는 경우에는 접속재 등을 이용하여 충분한 절연을 보강해야 하며, 접속재를 미설 치하거나 불량시공시 케이블 종단과 접속부의 열화를 촉진 시키는 원인이 되어 케이블 사고를 일으킬 수 있다.

케이블 종단의 반도전층 끝부분은 전계가 집중되어 절연 파괴가 쉽게 일어날 수 있지만, 단말처리가 되면 전계가 균일하게 분포되어 절연체 파괴 방지의 효과가 있고, 케이 블 접속부의 오염과 습기를 방지하여 트래킹(Tracking) 등에 의한 사고를 방지할 수 있다(Kim et al., 2009). 케이블 종단접속부는 Fig. 2 와 같은 구조이며, 내아크성 재질로 구성된다.

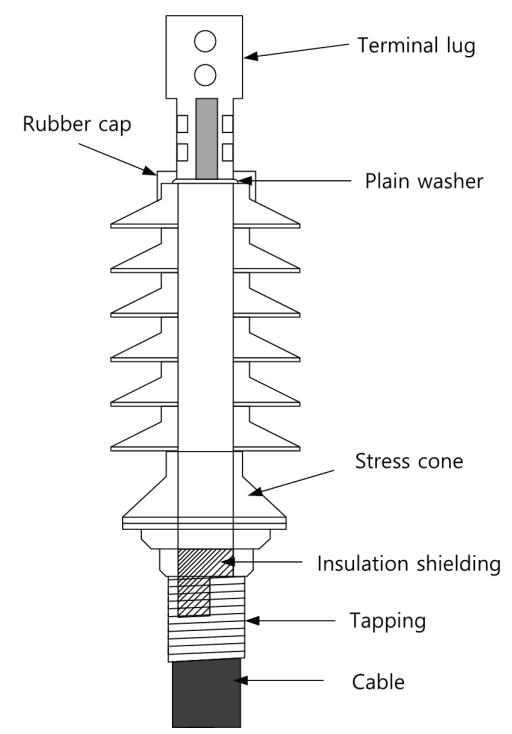

Fig. 2. Structure of Cable Head

\section{3. 정관에너지 화재사례 분석}

\section{1 화재 개요}

2017년 2월 9일 10:23경 부산 기장군 정관신도시 소재 부산정관에너지의 전기공급이 9시간 동안 중단되는 사고가 발생하였다. 화재 초기 언론에서는 변압기 폭발로 정관신도시 내 22,800여 가구 및 공공 상업시설에 정전이 발생하여 주민들 이 큰 불편을 겪었다고 보도하였으며, 이후 부산광역시 지방 경찰청은 정전사고와 관련된 인원 9 명을 불구속 입건하였다. 부산정관에너지(주)는 구역전기사업자로서 27,000여 가구 및 공공 상업시설에 전력 및 열을 공급하며, 전력설비는 $154 / 22.9 \mathrm{kV}$ 주 변압기 1대, 소내동력용 변압기 2대, 발전기 4대(G/T 2대, S/T 2대)로 구성되고, 계통은 Fig. 3과 같다.

사고 당시 $\mathrm{G} / \mathrm{T}$ 1대(G/T \#2)를 운전하여 정관 택지에 공급 하고 잉여전력은 한전측으로 역송전 중이었으며, G/T \#2 
선로의 계전기에서 지락이 감지되어 CB4144가 차단되면서 $\mathrm{G} / \mathrm{T} \# 2$ 발전기가 정지하고 발전 전원의 공급이 중단되었다. 이후 주변압기 전원측의 계전기(51)에서 과전류가 감지되면 서 $\mathrm{CB} 617$ 이 차단되고, 한전 전원의 공급이 정지되어 발전소 및 수용가 전체에 정전이 발생하였다.

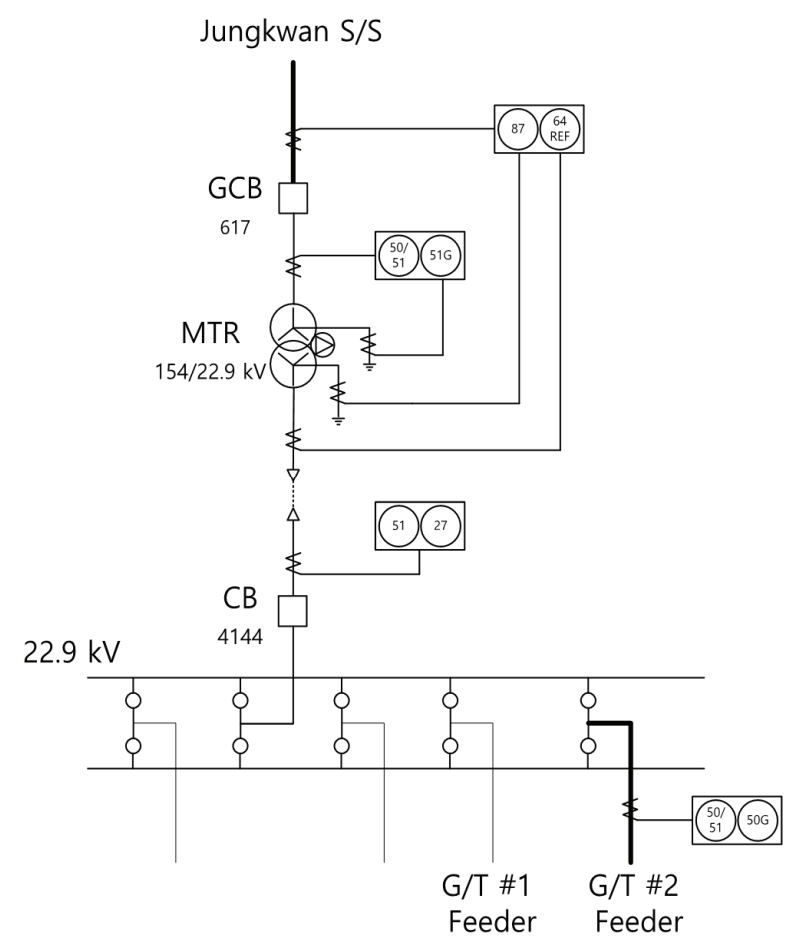

Fig. 3. Single Line Diagram

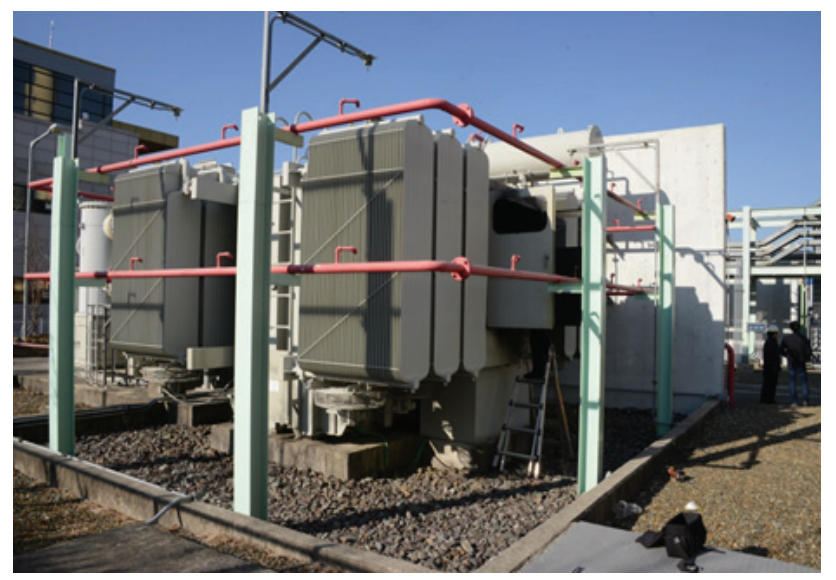

Fig. 4. Photo of Fire Scene

\section{2 현장조사}

화재가 발생한 부분은 옥외에 설치된 변압기 설비로써, Fig. 4와 같이 변압기 및 가스절연개폐기에서 탄화 및 소훼 형상은 확인되지 않고, $154 / 22.9 \mathrm{kV}$ 변압기 2차측 철제함 내부의 케이블 종단접속 부분을 중심으로 탄화된 형상이 확인되었다.
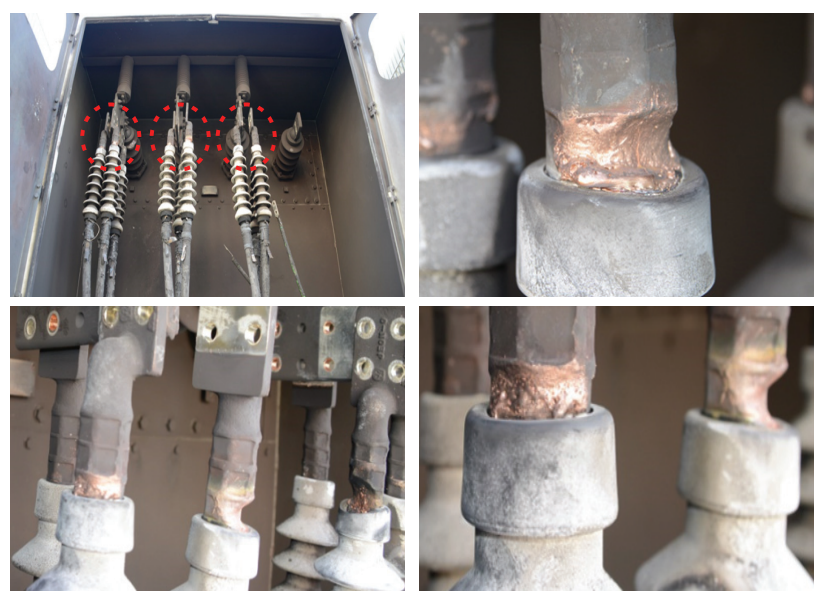

Fig. 5. Electric Arc of Cable Head

2차측의 철제함 내부에는 Fig. 5 와 같이 부싱 애자 4 개와 Insulator support 3 개가 설치되고, 각 상에는 3 개의 FR-CV $1 \mathrm{C} \times 400 \mathrm{~mm}^{2}$ 케이블이 설치된 구조로써, 3상의 케이블 헤드에서 단락 과정에서 형성된 다수의 전기적 용융흔이 확인되었다. 또한, Fig. 6 과 같이 철제함 내부 패널에서 B상의 케이블 헤드에 인접한 부분이 상대적으로 심하게 수열 및 열변색된 형상이 확인되었다.

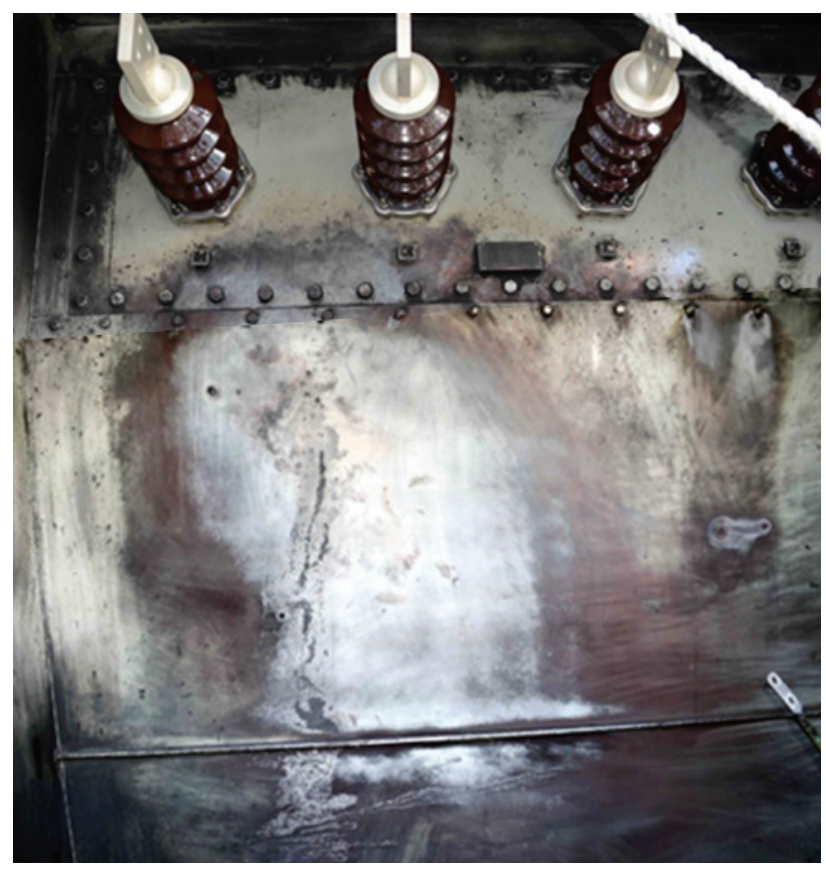

Fig. 6. Fire Pattern of Panel

\section{3 사고 데이터 분석}

사고 당시의 $\mathrm{G} / \mathrm{T} \# 2$ feeder 측 과전류계전기 고장파형은 Fig. 7과 같으며, 2017년 2월 9일 10시 23분경 최초 B상에서 지락 고장이 발생하였으며, B상 지락 이후 약 $63 \mathrm{~ms}$ 이후에 $\mathrm{A}$ 상 지락, 약 $137 \mathrm{~ms}$ 이후에 $\mathrm{C}$ 상에서 지락이 발생하였다. 


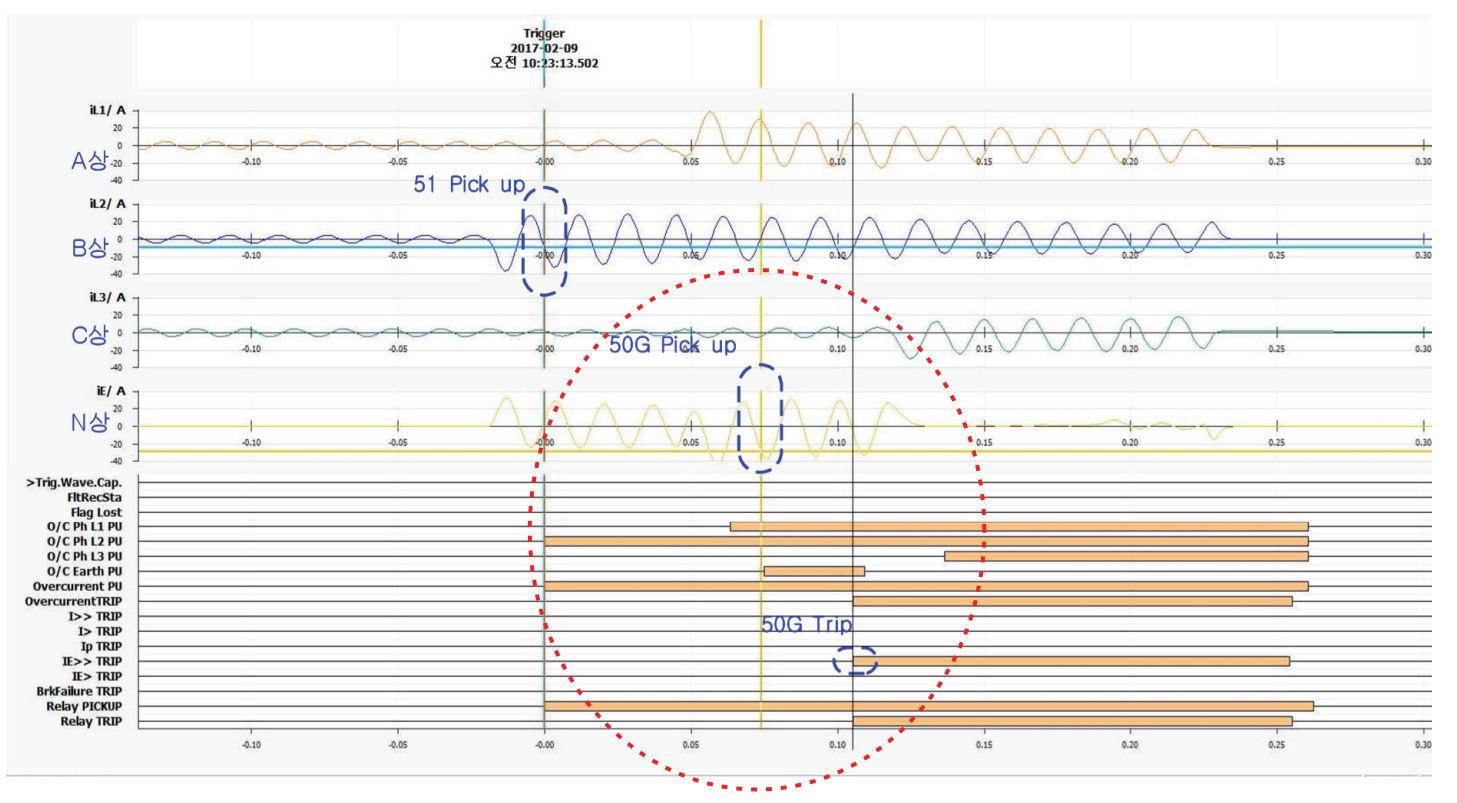

Fig. 7. Overcurrent Relay Data (G/T \#2 feeder)

이벤트 로그 데이터 역시 10 시 23 분경에 발전기 기동용 전원 LOSS, 워터펌프 전원 LOSS 및 $154 \mathrm{kV}$ 가스절연개폐기 트립 등의 경보가 발생한 점을 고려할 경우, 변압기 2차측 배선 중, $\mathrm{B}$ 상에서 최초 절연파괴에 따른 지락이 발생한 것으로 판단할 수 있다.

\section{$3.4 \mathrm{~B}$ 상 케이블 검사}

B상의 케이블 3선은 각각 B-1, B-2 및 B-3로 구분하였다. $\mathrm{B}$ 상의 케이블 종단접속부는 Fig. 8과 같이 전체적으로 심하 게 수열 및 변형된 형상이며, 특히 외관상 B-1의 케이블 헤드와 케이블 접속부의 절연테이프가 일부 소실되고, 심하 게 탄화된 형상이 확인되며, 절연저항 측정 시 B-1 케이블은 $0 \mathrm{M} \Omega$, 나머지 B-2 및 B-3 케이블은 2,000 MS으로 B-1 케이 블의 절연이 파괴된 것으로 확인되었다.
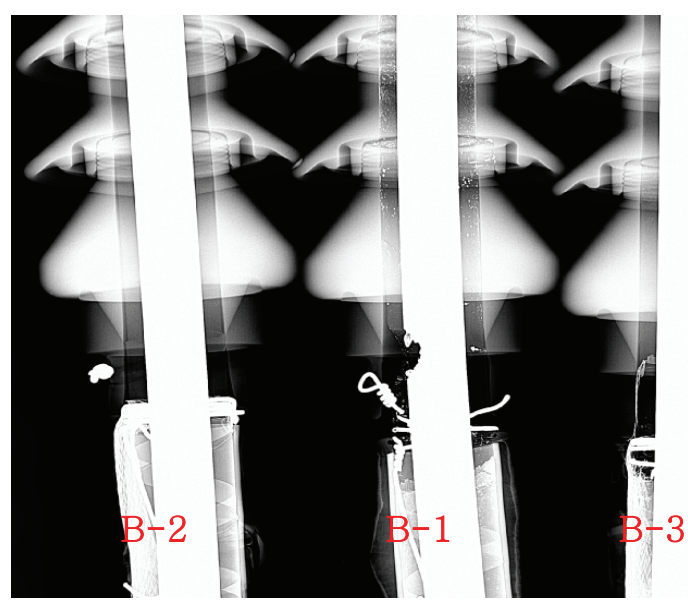

(a) B phase
$\mathrm{B}$ 상 케이블 종단접속 부분에 대한 X-ray 검사시, Fig. 9와 같이 B-1 케이블 내부의 도체와 차폐층에서 전기적으로

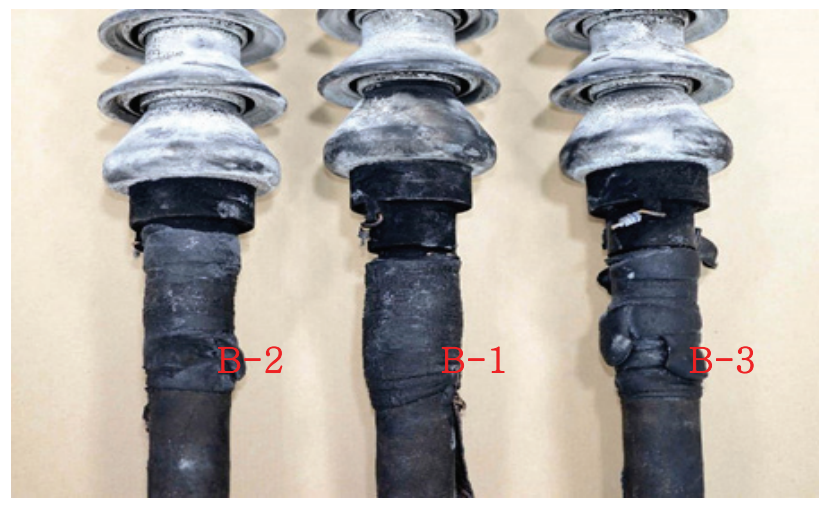

Fig. 8. Photograph of Power Cable (B phase)
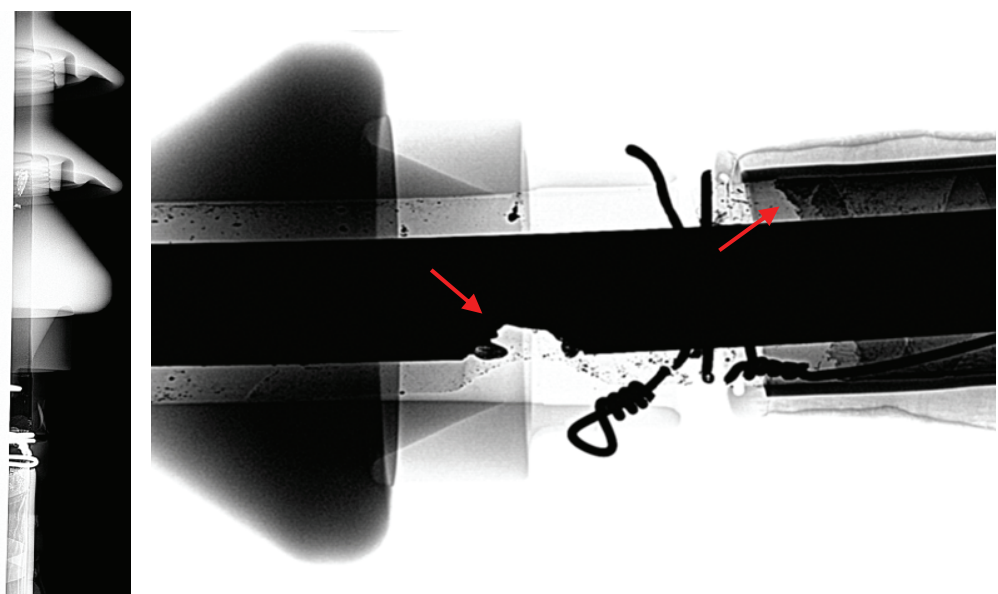

(b) B-1 cable

Fig. 9. X-ray Inspection 


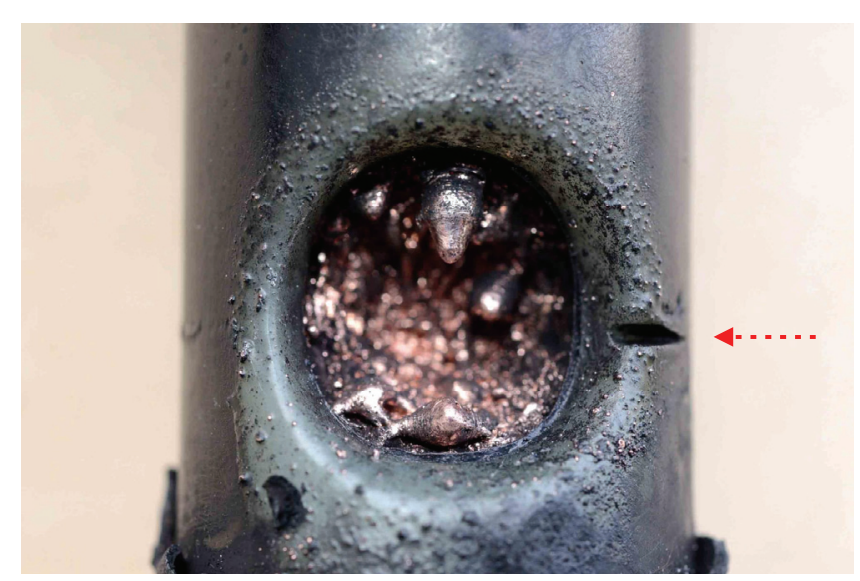

Fig. 10. Melted and Damaged Shape of Power Cable B-1

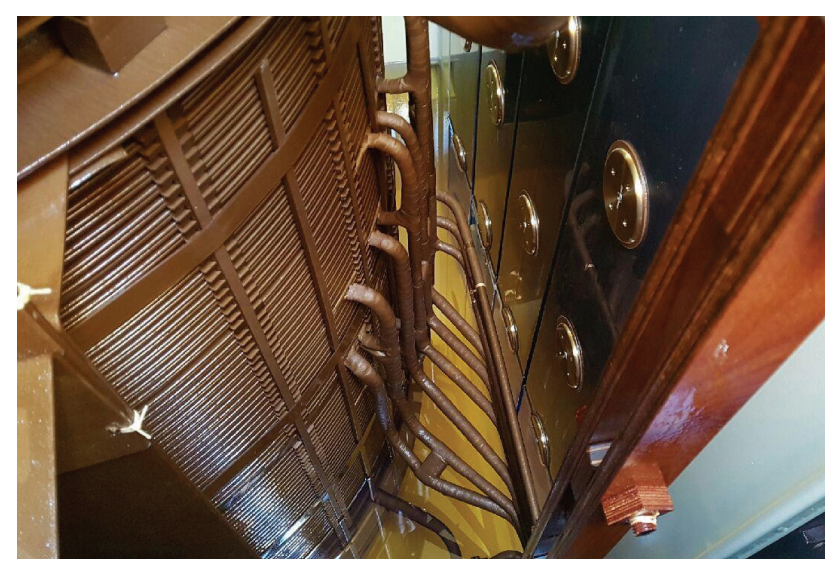

Fig. 11. Photograph of Inside of the Transformer

용융된 흔적이 확인되고, 주변에서 도체의 비산형상이 식별 되는 상태로서, 내부 도체에서 차폐층으로 지락이 발생한 것으로 판단된다.

케이블 종단접속 부분에 대한 분해 검사 시, B-1 케이블의 외부 반도전층 경계 부분을 중심으로 하여 절연체가 원형으 로 천공된 형상이며, 천공된 내측의 도체가 전기적 발열에 의해 용융된 형상이 확인되었다. 특히 Fig. 10과 같이 절연체 의 천공된 부위에서 도체에 수직방향으로 두께 약 $1 \mathrm{~mm}$ 정도 의 공구에 의해 손상된 흔적이 확인되었다. 이는 케이블 종단접속 부분의 절단 과정에서 손상된 흔적으로 판단되며, 손상흔적으로 볼 때, 절연체의 천공된 부분은 절연체가 내부 도체가 확인될 정도로 심하게 손상되었을 것으로 추정된다.

\section{5 변압기 이상 여부 검사}

케이블 화재는 과전압, 과전류의 영향으로 절연이 불량한 부분에서 발생할 수 있으므로, 주변압기의 이상여부에 대한 검사를 제조사를 통해 확인하였다. Fig. 11과 같이 변압기 내부에서 탄화 및 열변형 등 절연손상이 발생했다고 판단할 만한 특이점이 확인되지 않았으며, 일반적으로 변압기 상태

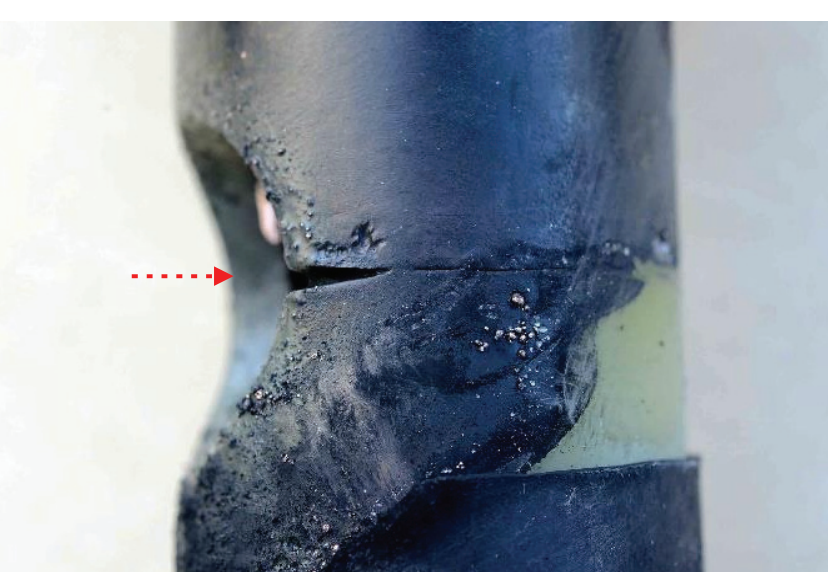

Table 1. Analysis data on Disolved Gases in Transformer

\begin{tabular}{c|c}
\hline Dissolved key Gas & Status (ppm) \\
\hline Hydrogen $\left(\mathrm{H}_{2}\right)$ & N/D \\
\hline Methane $\left(\mathrm{CH}_{4}\right)$ & 1 \\
\hline Ethylene $\left(\mathrm{C}_{2} \mathrm{H}_{4}\right)$ & $\mathrm{N} / \mathrm{D}$ \\
\hline Ethane $\left(\mathrm{C}_{2} \mathrm{H}_{6}\right)$ & $\mathrm{N} / \mathrm{D}$ \\
\hline Acetylene $\left(\mathrm{C}_{2} \mathrm{H}_{2}\right)$ & $\mathrm{N} / \mathrm{D}$ \\
\hline Carbon monoxide $(\mathrm{CO})$ & 43 \\
\hline Carbon dioxide $\left(\mathrm{CO}_{2}\right)$ & 238 \\
\hline
\end{tabular}

진단 시 이용되는 변압기 유증 가스 분석 결과, 수소, 메탄, 에탄, 에틸렌, 아세틸렌, 일산화탄소 및 이산화탄소가 Table 1 과 같이 정상치로 측정됨으로써, 주변압기 이상에 의한 화재 가능성은 배제할 수 있다(Sun et al., 2005).

\section{4. 결 론}

본 논문에서는 구역전기사업자인 (주)정관에너지에서 발 생한 화재사고에 대한 원인을 분석하였다. 초기 언론 보도와 는 달리 변압기 내부 검사 및 유증 가스 분석을 통해 변압기 이상에 의한 화재 가능성은 배제하였으며, 현장의 연소 형상, 케이블 종단 접속부의 소훼 형상, 사고 발생 시 제어시스템의 과전류계전기 데이터, 이벤트 로그 데이터 등의 분석을 통해 변압기 2차측의 케이블 종단접속 부분 중, $\mathrm{B}$ 상에서 최초 지락 고장이 발생하고, 이후 3 상 단락 과정에서 전기적 용융 흔적이 형성되면서 화재로 진전되었을 것으로 판단된다. 케이블 종단접속 부분의 X-ray 검사 및 분해 검사를 통해 B-1 케이블의 스트레스 콘 내부에서 절연체의 천공 흔적 및 도체의 전기적 용융흔적을 확인함으로써, B-1 케이블 내부에서 최초 지락 고장이 발생한 것으로 한정된다. 또한, 케이블 절연체의 천공된 부위에서 도체에 수직방향으로 
절단도구에 의한 손상흔적이 식별되는 상태로, 케이블 손상 부위에서 열화가 진행되면서 사고가 발생하였을 것으로 추정된다.

이처럼 케이블 종단접속부에서 손상부위가 발생할 경우, 장시간 경과 후에도 절연파괴 및 화재사고 등이 발생할 수 있는바, 설치시 시공관리에 더욱 신경을 써야 할 것이며, 지속적인 점검 및 유지보수를 통해 케이블에서의 사고를 예방하여야 할 것이다.

\section{감사의 글}

이 논문은 행정안전부 주관 국립과학수사연구원 중장기 과학수사감정기법연구개발(R\&D)사업의 지원을 받아 수행 한 연구임(NFS2020FSA02).

\section{References}

Bae, S.C. (2015). A study on the fire factors of power cable and rapid suppression method. Master's thesis, Yonsei University.

Choi, I.S. (2012). 10 years history of community energy system (May 22, 2012). Energy Newspaper. Retrieved from http://www.energy-news.co.kr/news/articleVie w.html?idxno $=10675$

Kim, J.H. (2019). A study on the reliability evaluation of power supply for community energy system. Master's thesis, Seoul National University.
Kim, Y.S., Shong, K.M., and Kim, S.G. (2009). The study of accident cases verification and construction of it's cause diagnosis system of power cable accident. Journal of the Korean Institute of Illuminating and Electrical Installation Engineers, Vol. 23, No. 9, pp. 91-97.

Korea Electric Power Corporation (KEPCO). (2019). Statistics of electric power in Korea.

LS Cable \& System Ltd. Retrieved from http://www. Iscns.co.kr/

Park, Y.J., and Lee, H.P. (2015). Identification on carbon oxide and smoke release change of aging wire cables. J. Korean Soc. Hazard Mitig., Vol. 15, No. 4, pp. 107-113.

Sun, J.H., Han, S.B., Kang, D.S., and Kim, K.H. (2005). Development of management software for transformers based on artificial intelligent analysis technology of dissolved gases in oil. Trans. KIEE., Vol. 54C, No. 12, pp. 578-584.

Taihan Electric Wire Co. Ltd. Retrieved from http://www. taihan.com/

\begin{tabular}{|l|l|}
\hline Received & March 12, 2020 \\
\hline Revised & March 16, 2020 \\
\hline Accepted & March 31, 2020 \\
\hline
\end{tabular}

